\title{
Very Silly Party Politics: Surrealism and Satire in the 'Pythonesque'
}

\begin{abstract}
2019 sees the $50^{\text {th }}$ anniversary of the iconic British television comedy series Monty Python's Flying Circus (BBC: 1969-74). This article focuses on the concept of 'Pythonesque', placing the broadly political satirical content that is evident within the Pythons' mainstream TV work and in selected subsequent film work at the centre of the notion of 'Pythonesque'. It will be suggested, moreover, that the Pythons' socio-cultural critical position is embedded in a long established British literary satirical tradition. Further, this article will aim to show that 'Pythonesque' incongruity, whilst adopting the aesthetic of the nihilistic cabaret of the Dadaists, was further influenced by the contemporary strain of British vernacular surrealism that permeated twentieth century popular performance through Music Hall, Variety comedy and The Goons, and also borrows Surrealist satirical perspectives. This evaluation of 'Pythonesque' fusion of satirical and surreal elements will posit that the comedians were simultaneously behind the times; of their time; and, in their prescience, some ways ahead of their time in their construction of humorous commentary on British societal mores and their vividly underscoring of the absurdity of the institutions they targeted.
\end{abstract}

Key Words Monty Python, Satire, Surrealism, Comedy, 'Pythonesque'

\section{The Pythons' Satirical Provenance}

In 1969, the Pythons first appeared on British television, bringing a startling mixture of punch-line eschewing sketches that featured a range of comedy grotesques - 'Pepperpot' women in drag, imbecilic 'Gumbys', a vengeful Spanish Inquisition and a series of interchangeable arguments with officialdom (BBC, 1969-74). Barsanti et al supply a very useful definition of the essence of Python:

In a broad sense, Monty Python was a Trojan horse of comedy, crammed with antiauthoritarianism, designed with Oxbridge erudition, and painted by Salvador Dali' (2017: xiii). 
Python's incubation came partly through a home-grown absurdist lineage seen most clearly in the acknowledged influence of the offbeat comedy 1950s radio work of The Goons (BBC, 1951-60). The Pythons held chief-Goon, comedian and writer Spike Milligan in particularly high regard and he would later appear in a cameo role in the Pythons' film Life of Brian (Jones, 1979). The Goons' radio sketch titles and subject matter can, in many ways, be seen as interchangeable with those of the Pythons' TV scripts. Compare, for example, the Goons' the Affair of the Lone Banana; the Great Bank of England Robbery; the MacReekie Rising of '74; or the History of Communications (Milligan, 1973) with the Pythons' Tunnelling from Godalming to Java; Bank Robber/Lingerie Shop; the Poet McTeagle; or How to do it (Chapman et al, 1989).

Where the Goons' ethos was purely and unabashedly silly, the Pythons also incorporated a satirical flavour within their comedy. This satirical strain had emerged through the 1960s university revue system finding its expression on TV through the new breed of Oxbridgeeducated comedians. The university revue phenomenon was first given life in the (then) revolutionary, albeit light-touch satirical, sketch comedy of Beyond the Fringe (Bennett et al, 1960). In this production Peter Cook, Alan Bennett, Dudley Moore and Jonathan Miller paved the way for a fresh and innovative viewpoint on the foibles of a, seemingly, no longer fit-for-purpose, post-war society:

I wish I could have got into judging circles. 'Cos, the trouble with being a miner is as soon as you're too old and tired and ill and sick and stupid to do your job properly, you have to go. But the very opposite applies with the judging. So all in all I'd rather have been a judge than a miner... (Bennett et al, 1960: 36).

Peter Cook's comic alter ego, spawned here in Beyond the Fringe, became E.L. Wisty, a character who always 'feels he is persecuted by...officials of all kinds' (Davis, 1989: 107); and opposition to authority is a strand that came to firmly permeated the Pythons' humour as they returned again and again to the theme of lampooning orthodoxy, taking it sometimes, to almost schoolboy-ish proportions. Peter Cook also worked on the innovative and influential satirical magazine Private Eye (1961- ) and this publication can also be seen, in turn, to have been hugely influential on the Python's house-style, as this extract from Cook's 1965 comic play/essay The Trial of Sir Basil Nardly Stoads indicates: 
Brigadier Thrames: I hesitate to interrupt, your holiness, but will you please be more explicit.

Reverend Prume: Let me say this, sir. The sin of St Arnolph was committed by the accused in no uncertain manner.

Brig. Thrames: Good evening.

Sir Basil was then asked to confirm or deny the accusation. There was a pause while a troop of small antelopes which had accompanied Sir Basil were asked to leave the court. He then read out the following prepared statement (reprinted by permission of the Morning Starborgling.)

"Gentlemen, ladies and fellow Seductives. It has been said, and rightly so, that there is a time and place for everything in the affairs of men. Was it not Winston Churchill himself, in common with Pascal, Diderot and Alphonse Enorme who deemed that the liberty of man is a sacred flame that we can ill afford to douse".

Brig. Thrames: Come to the point, come to the point. ((c) Private Eye: 1965, edition dated 22.1.65)

Pythonesque TV tropes abound in this extract. Authority state figures are put into ludicrous circumstances; a pompous Brigadier tries to get things back on track; incongruous animals appear; pompous erudition is undercut by absurdity; a Holy Grail-like mockery of English traditional and ritual prevails; even the inclusion of the name 'Basil' contains comic potential for the signalling of a very English type of eccentricity.

Peter Cook's own cabaret venture, The Establishment Club, opened in Soho in London in 1961 and adopted a formula of presenting hip, satirical sketches interspersed with musical items and more traditional stand-up comedy. Cook's staging of satirical content presented within a façade of zaniness led the way, in turn, for TV's initial attempts at blending topical comedy with sketches. That Was the Week That Was (BBC: 1962-63) and its successor The Frost Report (BBC: 1966-67) themselves drew further inspiration from the fashionable U.S. club and chat show circuit containing the satirical musings of comedians such as Mort Sahl, Stan Freberg and others. Wilmut (1980) and Barsanti et al (2017) trace the genesis of Monty Python's TV incarnations through several keynote programmes of the 1960s. As well as TW3 and The Frost Report, At Last the 1948 Show (ITV: 1967) and Do Not Adjust Your Set (ITV: 1967-69), allowed the Pythons variously to cut their teeth as writers and performers within light entertainment formats that blended sketches with mild political satire before they joined forces to create their own ensemble comedy. Given, then, that the all the Python 
team famously cut their teeth as writers during the 'satire boom' of the 1960s (Carpenter, 2000 ) it is impossible not to read satirical intent infiltrating their subsequent TV work. Indeed, mixing a relish for the absurd with a taste for broad-based satirical barbs, allied to a comic gusto that followed in the traditions of British Music Hall comedy, the Python's unique brand of lampoon, bizarreness, stream-of-consciousness and wariness of a traditional sketch format crystallised to form their own, distinctive brand of 1970's television work and created the concept of 'Pythonesque'. Throughout the four series of the Pythons' television show the comedians took broad iconoclastic swipes at banner British institutions, such as broadcasting, the retail sector, the Civil Service, the Church, and the Army. As Berger has it, the Python team were examples of 'egalitarians...that ridicule society and its institutions (and various elements in society, as well, such as the hierarchical elitists found in government, the church, etc.)' (1992: 62). In taking aim at such broad targets the Pythons' satire can, at best, be seen to be a form of playful invective, their humour 'spinning' attitudes and poking fun at sacred cows, rather than making any direct attempt to confront, change or criticise set socio-political positions. In essence, the Pythons took their critical lead from the British literary tradition of satire which aims to point out the follies of human behaviours, predicated on Jonathan Swift's 'techniques of irony and parody' (Stott, 2005: 113) imbued with 'astringent, intelligent glee' (Merchant, 1972: 42). In this lineage, as Highet puts it, 'the typical emotion which the author feels, and wishes to evoke...it is a blend of amusement and contempt' (1962: 21). The Pythons' work, ultimately, proves more like lampoon than pure satire. It is too weird and zany to contain real invective that bites or to hold up a 'truthful' mirror to society that calls anyone to account. It falls firmly into the category of Stott's definition of a more farcical comic form in which 'even though comedy often seems to be suspending, inverting, or abandoning dominant norms, these inversions are produced in relation to the cultural orthodoxies from which they must always begin' (2005:8). Indeed, as Wilmut notes, a typical Pythonesque television sketch is a safe confection of bizarre skits and light touch, parodic formulations:

The "format sketches" include a Panorama-type expose of men who dress up as mice... and a television discussion which proves rather unproductive because it is between a duck, a cat and a lizard (all stuffed). Several shows also have "vox pops" sections, parodying the street interviews with members of the public which tend to disfigure television coverage of election or budget days' (1980: 201). 
As satirists, then, the Pythons clearly operated very loosely within that continuum of expression of the form that Eric Weitz broadly characterises as 'a free-ranging mode of artistic attack, usually against some real or perceived orthodoxy in thought, attitude or practice' (2009: 184). But poking fun at orthodoxies was a mission that the Pythons apparently ceaselessly upheld in their constant targeting of large-scale social and cultural markers. The Pythons remorselessly and gleefully lambasted the Pillars of State and their authority figures and officers, throwing comic ammunition onto the heads of systems - class, the police, education, the arts, science, medicine, at experts of any kind. They pilloried the media, even, from time to time, targeting their own employers at the BBC, who, as Rick Hudson notes, were, at this period, institutionally 'seeking to maintain British ideology on a hegemonic level' (2017: 176). The Pythons also made comic capital out of the futility of life, taking as their stock-in-trade the simple disappointments and banalities of daily existence the difficulties of buying cheese in a cheese shop or the frustrations of being refused to take part in an argument for which one has paid. This comic nihilism ultimately found fullest expression in their 1983 film Monty Python's the Meaning of Life (Jones, 1983), an existentialist riff in the form of sketches on the sheer futilities of birth, sex and death. Michael Palin (in drag) ends the film by reading out the Python's comic definition of the "meaning of life":

Try to be nice to people, avoid eating fat, read a good book now and then, get some walking in, and try to live together in peace and harmony with people of all creeds and nations.

This explanation is then followed by the character going into a rant about the likelihood of 'gratuitous penises' that will be introduced into the film, designed purely to gratify gullible audiences. Crucially, the Pythons seems to suggests, it is, as ever the surrounding hype that will ultimately prevail over all else.

It is perhaps surprising that the Pythons as a team never made any claim for the adoption of any real politicised, anti-mainstream agenda or espoused the intentional taking of any revolutionary or satirical comic positions. Python's targets were seldom disruptive. Indeed, overall, Terry Gilliam's attitude towards censorship seems best to sum up generally the Pythons' philosophy on the targets of their attack in his statement, 'when I run up against...bureaucracy in whatever form it comes in - I seem to go berserk' (2015: 174). The 
Pythons can be seen to operate more like scattershot snipers, somewhat, in fact, like the incongruous French Guard in Monty Python and the Holy Grail (Gilliam and Jones, 1975), pouring both comic invective -"I fart in your general direction. Your mother was a hamster and your father smelt of elderberries" - and missiles of (non-sacred) cows, geese and other farmyard munitions onto the heads of King Arthur and his Knights of the Round Table . It is, perhaps, also not entirely insignificant that in simultaneously playing the French Guard attackers and the English Knight victims, the Python team were evidently being indiscriminate and even-handed in identifying and pursuing their comic aims and targets.

\section{The Pythons' Surrealist Provenance}

In many ways the Pythons' essential nihilism, along with their preferred expressive medium of provocative performance, echoed that of the Dadaists, some fifty years previously. In visual style, the addition of Terry Gilliam's collages firmly underlined the Pythons' drawing of inspiration from the stylisations of Dadaist Jean Arp's 'use of cut up paper, etc. [which] enabled him to break away from standard aesthetics' (Dachy, 2006: 30, in Forbes, 2017: 203). Like Dadaism, Pythonesque too co-opted music hall, film and heightened physical expressionism into its structure. Both movements enjoyed an overtly anarchic feel, seeming raw and rude with an over-the-top assertiveness at their core. The Dadaist Tristan Tzara described a gallery performance in Zurich in 1916 as, 'boxing resumed; cubist dance, costumes by Janco, each man his own big drum on his head' (Goldberg, 2001: 64). In creating its overall effects, this essential cabaret-style is, in significant ways, redolent of Python. As Adam Forbes notes:

Comedy is central to the Dadaist performances, the anarchic nature of the Dadaists, state that 'Laughter is a reaction to rigidity' (Richter, 2004, p.64). Opposing everything that was institutionalised, comedy was the source for their anarchic attack upon hegemony (2017: 213)

Politically, the idea of 'Dada Disgust' was something that Tzara placed at the heart of Dadaism in his manifesto, emphasising nihilistic scorn for 'every social hierarchy and equation set up for the sake of values by our values' (Tzara, 1918: 298). This, too, is an aesthetic that can be seen as central to the notion of 'Pythonesque'. 
The British Music Hall tradition had also enjoyed a strain of surrealism as is evident in this comic monologue from the comedian Dan Leno (1860-1904):

Eventually I reached Japan...I settled down there as a rhubarb merchant, and the next place to mine was a ginger beer plantation. He was a very nice fellow, the owner; he used to throw all the broken bottles into my garden. One morning when I was weeding the glass I happened to look up, and there I saw a woman trying to attract my attention. She winked at me with her ear - not her eye...so I walked over to her - I walked backwards to make people think I was coming away - and soon we were married (Hudd, 1968: 46).

The Pythons' expressive style became further distilled through a peculiarly English prism, that of 'British vernacular Surrealism ... one of the most dynamic forces in post-war British culture' (Lubbock, 2007: 3). For example, dramatically, the plot of N. F. Simpson's 1959 absurdist play One Way Pendulum is summarised by John Russell Taylor as follows:

Kirby Groomkirby stays constantly in his room upstairs trying to teach a collection of speak-your-weight machines the 'Hallelujah Chorus'...meanwhile downstairs his mother is always worrying what they would do with the left-over food if they did not pay Myra Gantry to come in and eat it all up...his aunt in her wheelchair is convinced she is touring the Outer Hebrides, and his father...is building a do-it-yourself Old Bailey in the living room (1963: 62-63).

This reads much like a Python sketch in its essential flavour, as in say, the Semaphore Version of 'Wuthering Heights', 'Julius Caesar' on an Aldis Lamp, or Crossing the Atlantic on a Tricycle (Chapman et al, 1989).

U.S. absurdist influences were also added into the Pythonesque, as Terry Gilliam noted regarding his earliest TV influences as a child in Minnesota, 'I think [Ernie] Kovacs, was the one who did more than anyone else to bring alive my interest in what I would later learn to think of as surreal comedy... he... introduced my receptive mind to the entertaining notion of a thing not having to be what it was' (2015: 10).

So, in essence, between 1969 and 1974, Pythonesque televised tropes demonstrated an inhouse comic flavour that revealed the satirical sensibilities of youngish, university-educated males imbued with a music hall surrealist and Dadaist cabaret vibe. The question must remain, however, as to whether the Pythons' essentially 'relentlessly anti-authoritarian' (Cogan and Massey, 2017: 135) satirical message was undermined by the surrealist and 
absurdist comic overtones or whether the cartoonish capering underscored the absurdity of the institutions targeted in the comic onslaughts?

\section{Pythonesque: Problems and Prescience}

On one hand, it is doubtless apparent that, in retrospect, the Pythons' comedy illustrates critical lapses on matters of race, class, race and gender depictions. It adopts a (very) male gaze and representations, and in general, tends to conform and confirm rather than to subvert contemporary prejudices. In presenting the mores and attitudes of the early 1970s, the Pythons seem to be very much of their time. It is sometimes difficult to separate where the Pythons' attitudes sought to reflect or to send up prevalent social and cultural trends in Britain in the 1970s. There is no doubt that, in retrospect, a fair slice of the Python canon is equally bedevilled by the lazy comic stereotyping that was the typical TV lingua franca of the period. Their Gumby characters, for instance - ape-like, bespectacled, moustachioed men with knotted handkerchiefs on their heads and with trousers rolled up at the knees, looking for all the world like 1930s seaside postcard caricatures of the older British working class man at the seaside, complete with their reductive catchphrase "my brain hurts" - is a thinly veiled, downward jab at a kind of inchoate, pre-'precariat' class. Perhaps partly because of the shorthand nature of the sketch format, simple reversals are too often used to make comic points about class, family, or socio-cultural institutions. These oppositions startle but contain few insights that go deeper or make much of a lasting impression. For instance, the obvious conceptual reversals in, say, Killer sheep or The Ideal Loon Exhibition do not go much further than their comic premise. Meanwhile, common use of the device of juxtaposing binary opposites in, for example, The Most Awful Family in Britain (while evenhandedly pointing out how awful families of all classes are) fails to register any meaningful points. Similar simple reversals used to create absurdist dissonance, such as the role swapping of father/son, north/south, arts/industry, erudition/stupidity in Working Class Playwright are showy comic pyrotechnics which burst out promisingly but too quickly fade. Some other more racially insensitive work, such as the British Consulate Smolensk section in The Cycling Tour or The North Minehead By-Election which features Nazi leaders hiding out in a Somerset boarding house are, today, a hard watch, containing gags that are difficult to hear. The sheer superficiality of the scope and uncertainty of the intended satirical target in the case of certain sketches can seem bluntly graceless retrospectively. As Critchley puts it, 
the Pythons work can be seen to be 'crammed full of rather worrying colonial and sexist assumptions' (2002: 74). Any potential Pythonesque critique seems undermined by the forceful grotesquery of the caricatures that are presented. Python's ethos, perhaps, in the end, is entirely like that of the Dadaists, in that, 'Dada provokes laughter...We [Dadaists] don't take anything seriously' (Danchev, 2011, p.176), in Forbes, 2017: 207).

In contrast, and, again, with the benefit of hindsight, the Pythons' TV work which still seems both funniest and most satirically radical is the sketches in which any (albeit large) target is made explicit and where there is no uncertainty about whom or what is the intended subject of the laughter. In operating as the 'comic relief' through their actions as critical commentators, the Pythons offer us a series of irresistible and durable invitations to laugh at those comic butts who seem most overtly to deserve mockery. Authority figures and the big institutions of state always seem ripe to be made fun of, and, the Pythons seldom fail to in deliver puncturing of pomposity. What remain today as 'classic' or iconic Python sketches appear to reveal the use of a mixture of satire on authority, use of British absurdity, and drawing on music hall comedy traditions to deliver relatively uncomplicated laughter responses. In the Ministry of Silly Walks, for example, po-faced, civil service officialdom is gloriously rendered absurd through the medium of eccentric dance. Existential futility is hilariously dissected in the crosstalk routine of the Dead Parrot sketch while The Lumberjack Song unpacks notions gender fluidity in an irresistibly surrealist style worthy of the Cabaret Voltaire.

On the other hand, Python's targets can also reveal a kind of prescient depth when viewed in retrospect. Take, for instance, the 1970 sketch Election Night Special in which the team parodied television General Elections coverage. The Pythons' routine clearly aimed at surrealism and absurdity, with, for example, the results in Luton revealing that 'the Silly party Candidate, Tarquin Fin-tim-lim-bim-lim-bin-bim-bin-bim bus stop F'tang F'tang Ole Biscuitbarrel beat both Alan Jones of the Sensible Party, and Kevin Phillips Bong, who was running on the Slightly Silly ticket'. However, with hindsight, something resembling genuine satirical bite is evident in this sketch than can have been immediately apparent at the time. In 1979 Margaret Thatcher became the first female Prime Minister of the United Kingdom. Her election victory was shown world-wide as she accepted her win in the Finchley constituency over a man wearing a large bucket on his head. A more truly Pythonesque 
moment is hard to imagine. Similarly, in the Brexit-saturated 2017 General Election, Lord Buckethead, in his latest reincarnation, was seen sharing a platform with Prime Minster Teresa May in the Maidenhead constituency. In the same televised results programme it was revealed that the incumbent M.P. for Uxbridge and South Ruislip's real name is Alexander Boris de Pfeffel Johnson and there was the glorious Farage-ist, linguistic coincidence of the inclusion in the original sketch of a Blackpool Central candidate comprising 'two frogs -- one called Kipper the other not, who have all gone 'Ni ni ni ni ni ni!' Meanwhile, in the Python sketch, the presenter (Cleese) ends up stating 'Oh I don't want to do this anymore, I'm bored!, neatly echoing the famous vox pop of 2017 from 'Brenda from Bristol' in regards to the forthcoming General Election, of 'Oh no. Not another one'! All a case, perhaps, of The Prophetically Pythonesque, just as Michael Palin's (Boring) Prophet character in Life of Brian summarises the situation, 'there shall be a great confusion as to where things really are...'?

The most presciently Pythonesque mixture of satire and surrealism in regards to today perhaps occurs in the film The Rise and Rise of Michael Rimmer (Billington, 1970) which Cleese and Chapman collaborated on, with Peter Cook's involvement, at the outset of the Python TV series transmission. Director Kevin Billington talked in 2011 about the film being 'of its time' but referred to its 'prescience on spin' adding that it was 'all connected with publicity, promotion, the media, the way that things are presented being the really important thing' (DVD extra, 2011). He also noted, doubtless apropos of the hideously

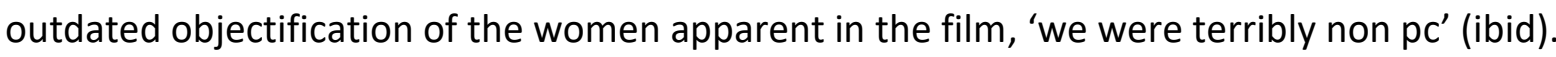
The film satirises the use of opinion polls and advertising as political influencers and contains a number of pertinently topical matters which are very familiar in a Brexitobsessed British society fifty years later. These include advice to a new Prime Minister to 'talk about things in terms of keeping our options open'; Tories using the issue of immigration as a means of influencing public opinion; politicians speculating against the pound and media cynicism about left wing politicians (complete with a widely disseminated press story about the leader of the opposition taking a physical tumble). Cook, as the Machiavellian Prime Minister comes around to arranging a referendum on every single major issue, which he characterises as 'participatory democracy'. He eventually cynically calls a referendum on his own 'presidential' bid, in which $82 \%$ of public vote for him. 
The subsequent appropriation of Python itself also provides a kind of prescient satirical legacy. In 1990 Margaret Thatcher quoted the Dead Parrot sketch at the Tory Party conference to refer to the Liberal Democrat party - 'this is an ex-parrot...it is not merely stunned, it has ceased to be, expired and gone to meet its Maker...'. The image was rehashed by The Sun Newspaper (6th October 1998) to depict the likely demise of the Tory Party under the then leader, William Hague. Iconic sketches are often referenced by cartoonists and commentators as a kind of political shorthand or are re-used as a social or cultural comic metaphor. Take The New Yorker's use of the Python's Ministry of Silly Walks sketch in 2016 ( $4^{\text {th }}$ July edition) which shows bowler-hatted Men from the Ministry taking an eccentric cliff-edge Brexit walk. Meanwhile, later Python tropes such as the wildly selfdelusional, dismembered Black Knight from Holy Grail has been appropriated by the same publication to depict President Donald Trump's perceived position in his dealings with the USA's governing and legislative chambers.

A further illustration of how the Pythonesque influenced a view of the UK's socio-political systems is evident in a recent appropriation of their work. The original What Have the Romans Ever Done For Us? sequence from Life of Brian, builds to the following:

Reg: All right, but apart from the sanitation, the medicine, education, wine, public order, irrigation, roads, the fresh-water system, and public health, what have the Romans ever done for us?

PFJ Member: Brought peace?

Reg: Oh, peace? SHUT UP! (Monty Python's Life of Brian, Jones, 1979).

In 2016 a Guardian-sponsored sketch starred the actor Patrick Stewart as a government minister summing up on the issue of the benefits of the European Court of Human Rights:

Minister: Alright, apart from the right to a fair trial, right to privacy, freedom of religion, freedom of expression, from discrimination, freedom from slavery, torture and degrading treatment, and protecting victims of domestic violence ...peace in Northern Ireland... what has the ECHR done for us?

Member: The Bill of Rights?

Minister: Oh fuck off! (The Guardian: 25/4/16).

Apropos the unprecedented bonfire of national governance that has occurred in the UK since the Brexit referendum, a recent commentator notes, 'one of the strongest lessons of 
this period is that we need a wholesale reimagining of our institutions so that they better serve the rest of us, rather than just those who run them' (Chakrabortty, 2019).

To conclude, a definition of Pythonesque peculiarly blends satire with British surrealism. As an example of the phenomenon, a meta-Pythonesque manifestation actually surrounded the controversy about blasphemy that was caused by the Life of Brian, a film which simply 'parod[ied] the absurdities of religious belief' (Carpenter, 2000: 305). Invited onto a televised debate programme to account for their stance on the film's themes, the footage of Palin and Cleese on Friday Night, Saturday Morning (BBC: 1979-82) attempting to justify their position to the Christian broadcaster Malcolm Muggeridge and Mervyn Stockwood, the be-cassocked Bishop of Southwark, is almost indistinguishable from a Python TV sketch. The complainants' pomposity, condescension and seemingly wilful missing-of-the-point reveal a suitably Pythonesque depiction of orthodoxy behaving at its most entitled. The encounter would later provided rich material for another subsequent group of, mainly Oxbridge, TV comedy satirists in Not the Nine O'clock News (BBC: 1979-82), a programme which itself 'aimed to blend Monty Python-style surrealism with a degree of topical satire' (Carpenter, 2000: 324). Their Life of Python Synod sketch fabricated a reversal in which a bishop was forced to defend his new film, the General Synod's Life of Christ, against the claim that it was a blasphemous slur on the revered members of Python.

Pythonesque's satirical and surrealistic flavour has also come to mean a depiction of an extreme, parodic presentation of peculiarly British nostalgia and triumphalism, seen through the mischievous prism of a mythologized past. This absurdist denotation of British-ness sprang from Terry Jones and Michael Palin's earlier TV work on The Complete and Utter History of Britain (LWT: 1969) which begat in turn, Ripping Yarns $(1976-77,1979)$ and Jabberwocky (1977) before finding full expression in The Holy Grail and Spamalot. Pythonesque appropriation, in the sense of legendary Anglicisation, can also be seen to have influenced other unconnected British TV productions, such as Cabbages and Kings (BBC: 1972-74), Blackadder (BBC: 1983-89), Horrible Histories (BBC: 2009- present) and, onstage, Rory Mullarkey's 2016 play St. George and the Dragon at the National Theatre (REF). All these works are avowedly Pythonesque and each relies on the conjuring up of 
mythic stereotypes and allow for sly depictions of a backward-looking visions of a skewed 'Englishness', made for comic effect.

In the end, the Pythons can be seen to have invented a wholly unique genre of comic political and social satire. In capturing the spirit of the old Establishment Club in which, as Bamber Gascoigne noted, there was 'there was an immediacy, a sense of danger and the unexpected' (in Wilmut, 1980: xiii) and making it happen on television and film, a notion of Pythonesque has firmly entered the lexicon of comic definition. Python's brand of anarchic absurdity, satirical lampoonery and appropriated Music Hall brio will forevermore be viewed more widely around the globe as epitomising a special kind of quintessentially English surreal and satirical humour. It also provides a critical shorthand for apparently absurd political decision-making. For instance, as was noted in a recent article in The London Evening Standard newspaper, British Foreign Secretary Jeremy Hunt was quoted as saying '"the clash and thunder over Brexit is not an appealing spectacle. Some may feel that British politicians are acting out 'Monty Python' sketches in real life"' (Cecil, 2019: 6).

\section{References}

Barsanti, Chris; Cogan, Brian; Massey, Jeff (2017) Monty Python FAQ: All That's Left to Know about Spam, Nudging, Bruces, and Spam, Milwaukee, Wl; Applause Theatre \& Cinema Books Bennett, Alan; Cook, Peter; Miller, Jonathan; Moore, Dudley $(1960,1991)$ Beyond the Fringe, London: Samuel French Ltd.

Berger, Arthur Asa (1992) Popular Culture Genres: Theories and Texts, London: Sage Carpenter, Humphrey (2000) That Was Satire That Was: The Satire Boom of the 1960s, London: Victor Gollancz

Cecil, Nicholas (2019) 'Brexiteers turn on each other as dream fades'. In The Evening Standard Newspaper, 29th March 2019 
Chakrabortty, Aditya (2019) 'Amoral and venal: Britain's governing class has lost all sense of duty'

https://www.theguardian.com/commentisfree/2019/mar/27/brexit-referendumconservative-party

Chapman, Graham; Cleese, John; Gilliam, Terry; Idle, Eric; Jones, Terry and Palin Michael (1989), Monty Python's Flying Circus: Just the Words Volume Two, London: Guild Cogan, Brian and Massey, Jeff (2017) 'Joining the Circus: The Pythons Before Monty Python'. In Reinsch, Paul N., Whitfield, B. Lynn and Weiner, Robert G, (eds.) (2017) Python Beyond Python: Critical Engagements with Culture, London: Palgrave MacMillan Critchley, Simon (2002) On Humour, Abingdon, Oxon: Routledge Dachy, Marc. (2006) Dada -The Revolt of Art (Discoveries). London: Thames and Hudson. Danchev, Alex (2011) 'A century of blasting and blessing: the history of hectoring.. The Independent, February 11, 2011. Accessed online at:

https://www.independent.co.uk/arts-entertainment/books/features/a-century-of-blastingand-blessing-the-history-of-hectoring-2210893.html

Davis, Anthony (1989) Laughtermakers: The Story of TV Comedy, London: Boxtree Ltd. Forbes, Adam (2017) 'Nihilistic light entertainment and metamorphic linkages: dada and contemporary comedy'. Comedy Studies, Vol 8 No 2, April-August 2017, pp 197-216.

Gilliam, Terry and Thompson, Ben (2015) Gilliamesque, Edinburgh: Canongate Goldberg, RoseLee (2001) Performance Art: From Futurism to the Present, London: Thames and Hudson

The Guardian (2016) 'What has the ECHR ever done for us?' Accessed online at: https://www.theguardian.com/culture/video/2016/apr/25/patrick-stewart-sketch-whathas-the-echr-ever-done-for-us-video

Highet, Gilbert (1962) The Anatomy of Satire Princeton, New Jersey; Princeton University Press.

Hudd, Roy (ed.) (1968), Dan Leno Hys Booke, London: Hugh Evelyn. Hudson, Rick (2017), 'Thrilling Adventures in Post-Colonial Culture: From Empire to Commonwealth in Ripping Yarns and British Popular Culture. In Reinsch, Paul N., Whitfield, B. Lynn and Weiner, Robert G, (eds.) (2017) Python Beyond Python: Critical Engagements with Culture, London: Palgrave MacMillan Lubbock Tom (2007), 'That's really surreal ...', The Independent, 23 March 2007. 
Merchant, Moelwyn (1972) Comedy, London: Methuen and Co.

Milligan, Spike (1973), The Goon Show Scripts, London: Sphere.

Private Eye (1965) The Penguin Private Eye, Harmondsworth, Middlesex: Penguin

Ritcher, Hand and Britt, David (2004) Dada: Art and Anti-Art, London: Thames \& Hudson

Russell Taylor, John (1963) Anger and After: A Guide to the New British Drama,

Harmondsworth, MX: Pelican

Stott, Andrew (2005) Comedy, Abingdon Oxon: Routledge

Tzara, Tristan (1918) Dada Manifesto. In Motherwell, Robert (ed.), (1951) The Dada Painters

and Poets: An Anthology, New York: George Whittenbarn

Weitz, Eric (2009) The Cambridge Introduction to Comedy, Cambridge, Cambridge University Press

Wilmut, Roger (1980) From Fringe to Flying Circus, London: Eyre Methuen

\section{$\underline{\text { Bio Details }}$}

Ian Wilkie is a Lecturer in Performance at the University of Salford. His PhD is in Comic Performance. He is the Editor of Comedy Studies and the author of Performing in Comedy: a Student's Guide (Routledge: 2016).

Contact details: Room 6:02, New Adelphi Building, University of Salford, M5 4BR

E-mail: I.Wilkie1@salford.ac.uk 
